\title{
Predicting the relative humidities of liquid-liquid phase separation, efflorescence, and deliquescence of mixed particles of ammonium sulfate, organic material, and water using the organic-to-sulfate mass ratio of the particle and the oxygen-to-carbon elemental ratio of the organic component
}

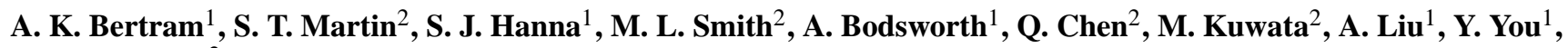 \\ and S. R. Zorn ${ }^{2}$ \\ ${ }^{1}$ Department of Chemistry, University of British Columbia, Vancouver, BC CAN V6T 1Z1, Canada \\ ${ }^{2}$ School of Engineering and Applied Sciences \& Department of Earth and Planetary Sciences, Harvard University, \\ Cambridge, Massachusetts, USA
}

Received: 5 June 2011 - Published in Atmos. Chem. Phys. Discuss.: 23 June 2011

Revised: 6 October 2011 - Accepted: 11 October 2011 - Published: 7 November 2011

\begin{abstract}
Individual particles that on a mass basis consist dominantly of the components ammonium sulfate, oxygenated organic material, and water are a common class of submicron particles found in today's atmosphere. Here we use (1) the organic-to-sulfate (org:sulf) mass ratio of the overall particle and (2) the oxygen-to-carbon (O:C) elemental ratio of the organic component as input variables in parameterisations that predict the critical relative humidity of several different types of particle phase transitions. Specifically these variables were used to predict the critical relative humidity of liquid-liquid phase separation (SRH), efflorescence (ERH), and deliquescence (DRH). Experiments were conducted by optical microscopy for 11 different oxygenated organic-ammonium sulfate systems covering the range $0.1<$ org:sulf $<12.8$ and $0.29<\mathrm{O}: \mathrm{C}<1.33$. These new data, in conjunction with other data already available in the literature, were used to develop the parameterisations SRH(org:sulf, O:C), ERH(org:sulf, O:C), and DRH(org:sulf, $\mathrm{O}: \mathrm{C})$. The parameterisations correctly predicted SRH within $15 \%$ RH for $88 \%$ of the measurements, ERH within $5 \%$ for $84 \%$ of the measurements, and DRH within $5 \%$ for $94 \%$ of the measurements. The applicability of the derived parameterisations beyond the training data set was tested against observations for organic-sulfate particles produced in an environmental chamber. The organic component consisted of
\end{abstract}

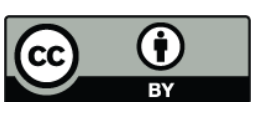

Correspondence to:

A. K. Bertram (bertram@chem.ubc.ca),

S. T. Martin (smartin@seas.harvard.edu) secondary organic material produced by the oxidation of isoprene, $\alpha$-pinene, and $\beta$-caryophyllene. The predictions of the parameterisations were also tested against data from the Southern Great Plains, Oklahoma, USA. The observed ERH and DRH values for both the chamber and field data agreed within $5 \%$ RH with the values predicted by the parameterisations using the measured org:sulf and $\mathrm{O}: \mathrm{C}$ ratios as the input variables.

\section{Introduction}

Atmospheric aerosol particles have many important roles in the Earth system. Examples include their feedback mechanisms to climate change, their links to the biogeochemical cycles of many elements, and their effects on regional visibility and human health (Finlayson-Pitts and Pitts, 1997; Ravishankara, 1997; Martin et al., 2004; Pope and Dockery, 2006; Seinfeld and Pandis, 2006; Forster et al., 2007). In the atmosphere, single particles having both organic and sulfate species are abundant (Murphy et al., 1998; Buzorius et al., 2002; Murphy et al., 2006; Pratt and Prather, 2010). Since the sulfate fraction is often partially or fully neutralised by ammonium (Dibb et al., 1996; Huebert et al., 1998; Talbot et al., 1998; Dibb et al., 2000; Lee et al., 2003), mixed organic-ammonium sulfate particles constitute an important class of atmospheric aerosol particles.

Published by Copernicus Publications on behalf of the European Geosciences Union. 


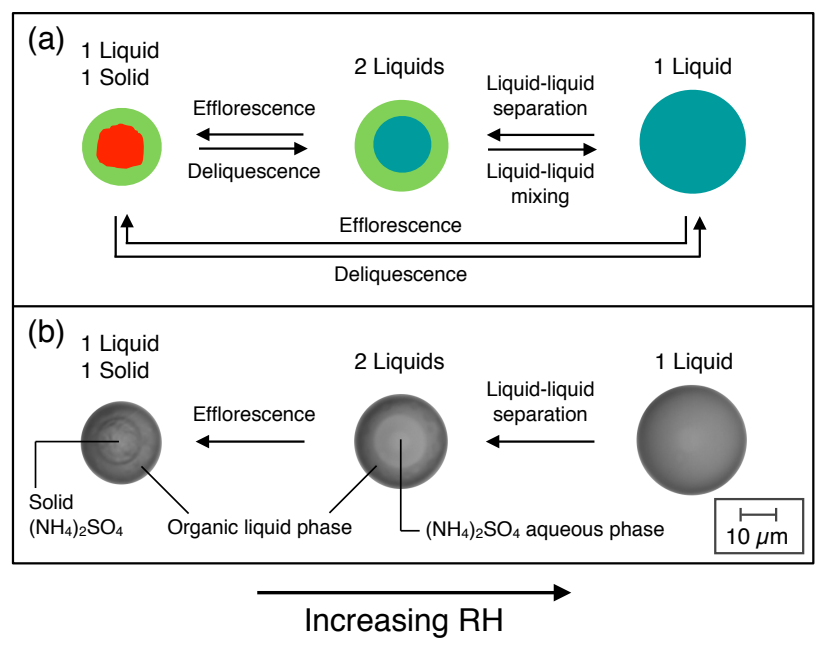

Fig. 1. (a) Some possible phase transitions of mixed organicammonium sulfate particles. These transitions can occur as atmospheric relative humidity fluctuates between high and low values. Aqua, green, and red respectively represent an aqueous phase, a liquid phase of organic material, and a solid phase of crystalline ammonium sulfate $\left(\left(\mathrm{NH}_{4}\right)_{2} \mathrm{SO}_{4}\right)$. (b) Optical microscope images of a single particle consisting of 1,2,6-trihydroxyhexane and ammonium sulfate (org:sulf $=2.1$ ) showing the sequence from right-to-left of an internally mixed liquid phase, two phase-separated liquids, and a core-shell arrangement of a solid-liquid particle. Images were recorded using $500 \times$ magnification as the relative humidity was decreased while the temperature was held constant at $291 \pm 1 \mathrm{~K}$.

Individual organic-ammonium sulfate particles can undergo liquid-liquid phase separation, efflorescence, and deliquescence as the relative humidity ( $\mathrm{RH})$ cycles between low and high values during air parcel motion and temperature oscillations in the atmosphere (e.g., Martin, 2000; Clegg et al., 2001; Brooks et al., 2002; Pankow, 2003; Parsons et al., 2004; Erdakos et al., 2006; Marcolli and Krieger, 2006; Anttila et al., 2007; Ciobanu et al., 2009; Prisle et al., 2010; Zuend et al., 2010; Smith et al., 2011). These phase transitions are illustrated in Fig. 1a. In the past, researchers trying to determine the phase transitions of organic-ammonium sulfate particles focused mainly on the individual organic molecules that have been identified in the atmosphere (e.g., Brooks et al., 2002; Wise et al., 2003; Braban and Abbatt, 2004; Parsons et al., 2006). In the atmosphere, however, the organic fraction in these mixed particles consists of 1000s of different molecules, with only about $10 \%$ molecularly identified (Hallquist et al., 2009). Because only a small fraction of the organic material of atmospheric particles have been identified, liquid-liquid phase separation, efflorescence, and deliquescence of mixed organic-ammonium sulfate particles have been difficult to anticipate. Herein, given the intractability of characterising and studying 1000 s of individual organic molecules, we explore a different approach by focusing on the organic-to-sulfate (org:sulf) mass ratio of the mixed particles and the oxygen-to-carbon $(\mathrm{O}: \mathrm{C})$ elemental ratio of the organic component as possible predictors of phase transitions. The practical advantage of using these ratios is that they are measured by instrumentation that has already been deployed at measurement sites worldwide (Jayne et al., 2000; Zhang et al., 2007; Aiken et al., 2008; Jimenez et al., 2009; $\mathrm{Ng}$ et al., 2010).

This presentation of the current study is structured, as follows. In Sect. 2, laboratory measurements of deliquescence, efflorescence, and liquid-liquid phase separation are described for particles containing one oxygenated organic molecule plus ammonium sulfate and water (i.e., threecomponent particles). Oxygenated organic molecules are a major fraction of the total organic particle mass concentration in the atmosphere, and they dominate relative to nonoxygenated organic molecules on a global-average mass basis (Kanakidou et al., 2005; Zhang et al., 2007; Hallquist et al., 2009). Each studied system consisted of one type of oxygenated organic molecule, plus ammonium sulfate and water (Tables S1-S3). Functional groups included esters, alcohols, carboxylic acids, ethers, and aromatics. This selection covers many of the functional groups found in the atmosphere (Finlayson-Pitts and Pitts, 1997; Seinfeld and Pandis, 2006; Day et al., 2009; Liu et al., 2009; Russell et al., 2011). In Sect. 3, the new laboratory results as well as other laboratory results reported in the literature are summarised and discussed, and the parameterisations of the laboratory results are presented. In Sect. 4, we apply the parameterisations to two case studies: an environmental chamber study and a field study. Section 5 presents conclusions and outlook.

\section{Experimental}

The relative humidity at which liquid-liquid phase separation (SRH), efflorescence (ERH), and deliquescence (DRH) occurred in 11 different oxygenated organic-ammonium sulfate systems was studied with an optical microscope coupled to a temperature controlled flow-cell (Pant et al., 2006; Ciobanu et al., 2009; Bodsworth et al., 2010). The bottom surface of the flow cell was a hydrophobic glass slide upon which the particles were deposited and observed. A solution of ammonium sulfate and an organic molecule was prepared in highpurity water or, in the case of low water-solubility organic molecules, in a mixture of water and methanol. The solution was then passed through a nebulizer to produce submicron droplets. These droplets were directed toward the hydrophobic glass slide, upon which they deposited and coagulated into supermicron droplets. The water or the water/methanol mixture was then evaporated to generate organic-ammonium sulfate particles with lateral dimensions ranging from 10 to $30 \mu \mathrm{m}$

At the beginning of an experiment the $\mathrm{RH}$ in the flow cell was first set to nearly $100 \%$. Relative humidity was controlled by a continuous flow of a mixture of humid and dry 
(a) $\mathrm{SRH} \mathrm{O:C}<0.7$

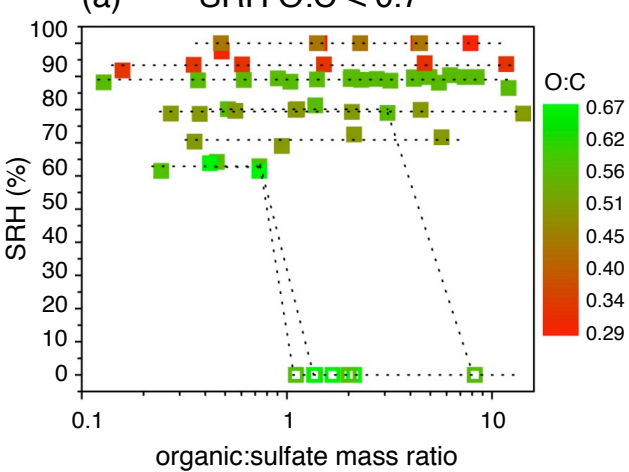

(c) $\mathrm{DRH}$ and $\mathrm{ERH}$ for $\mathrm{O}: \mathrm{C}<0.7$

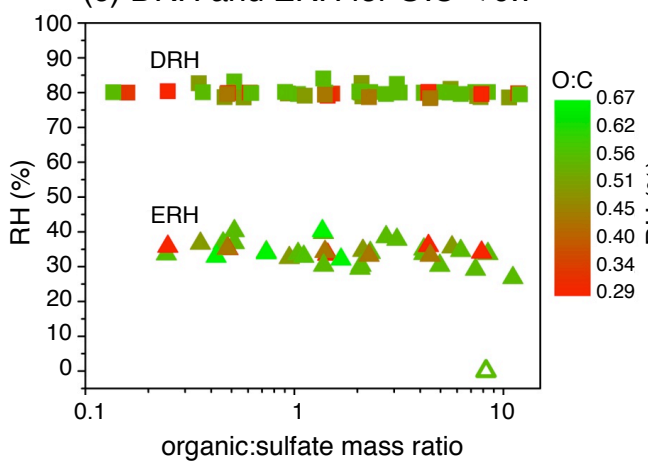

(b) $\quad \mathrm{SRHO} \mathrm{O}: \mathrm{C}>0.7$

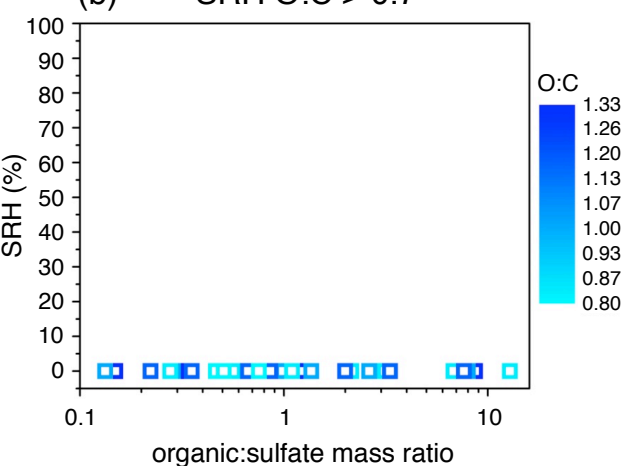

(d) $\mathrm{DRH}$ and ERH for O:C $>0.7$

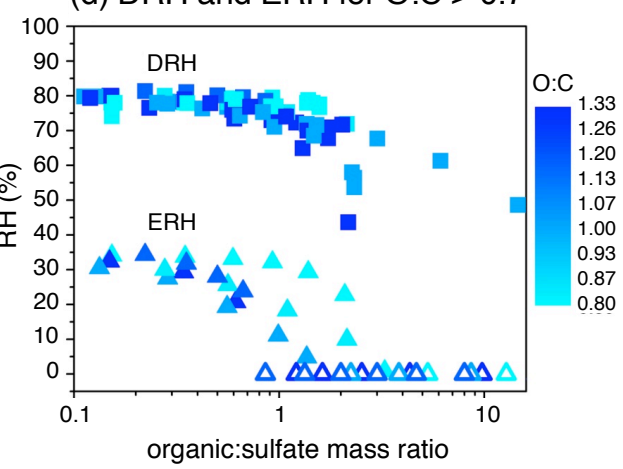

Fig. 2. Measurements of separation relative humidity (SRH), efflorescence relative humidity (ERH), and deliquescence relative humidity (DRH). Axes denote the observed relative humidity $(\mathrm{RH})$ of a transition and the organic-to-sulfate mass ratio of a studied mixed system. Data are segregated between the left and right sets of panels for low $(<0.7)$ and high $(>0.7)$ oxygen-to-carbon $(\mathrm{O}: \mathrm{C})$ elemental ratios of the organic material. Open symbols indicate that no phase transition was observed. In some cases SRH was not probed below 35-40\% RH because ammonium sulfate or the organic material crystallised. Phase transitions for temperatures ranging from 290 to 298 K.

$\mathrm{N}_{2}$. The relative humidity of the gas was determined using a chilled mirror sensor (General Eastern). The uncertainty in measuring the relative humidity of the carrier gas was $0.3 \%$, and the uncertainty in the reported SRH, ERH and DRHvalues were $2.5 \%, 2.8 \%$, and $2.5 \%$, respectively, based on the reproducibility of the data. Typical flow rates were approximately $1.5 \mathrm{~L} \mathrm{~min}^{-1}$. After initialisation at nearly $100 \%$ $\mathrm{RH}$, the $\mathrm{RH}$ over the particles was then ramped down at a rate of $0.4-0.6 \%$ per minute, and images of the particles were captured every approximately $20 \mathrm{~s}$. The RH was decreased to approximately $25 \%$ if efflorescence was observed and to as low as $2 \%$ if no efflorescence was observed. After efflorescence was observed or the particles had been held at $<2 \%$ $\mathrm{RH}$ for some time, the RH was increased at the same rate to observe deliquescence of the particles. Calibration of the absolute $\mathrm{RH}$ readings was done using the DRH values for pure ammonium sulfate particles. All experiments were carried out at a temperature of $290 \pm 1 \mathrm{~K}$, except for experiments with 1,2,6-trihydroxyhexane. The results reported for 1,2,6trihydroxyhexane were carried out at $273 \pm 1 \mathrm{~K}$ though several experiments were also conducted at $290 \pm 1 \mathrm{~K}$ and con- firmed that within experimental uncertainty the DRH, ERH, and SRH were the same at both temperatures.

The spatial distribution of the organic and sulfate material after liquid-liquid phase separation was probed with Raman microscopy at approximately 293 K. Raman spectra of a pure ammonium sulfate particle, a pure 4-dihydroxy3-methoxybenzeneacetic acid particle, and a mixed 4dihydroxy-3-methoxybenzeneacetic acid-ammonium sulfate particle (org:sulf of 3.1) were collected. Spectra were acquired on particles deposited on a hydrophobic glass slide in the same manner as for the optical microscope experiments. The spectra were collected using a Renishaw inVia Raman microscope with excitation using an argon ion laser at $514 \mathrm{~nm}$ and a power of $200 \mathrm{~mW}$. All Raman spectra were collected at room temperature. For the Raman experiments the particles were exposed to room air, and hence, the RH was not controlled. 


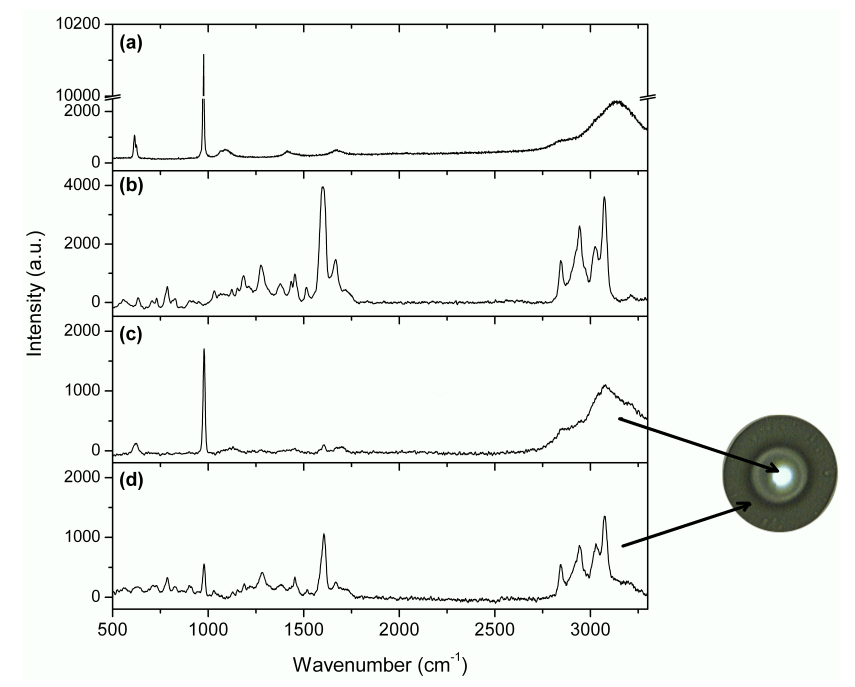

Fig. 3. Raman spectra of (a) a pure ammonium sulfate particle, (b) a pure 4-dihydroxy-3-methoxybenzeneacetic acid particle, (c) the core of a mixed 4-dihydroxy-3-methoxybenzeneacetic acidammonium sulfate particle after phase separation, and (d) the shell of a mixed 4-dihydroxy-3-methoxybenzeneacetic acid-ammonium sulfate particle after phase separation. The mixed particle used for Raman analysis (organic-to-sulfate $=1.44$ ) is shown to the right. All Raman spectra were collected at approximately 293 K. In addition, during Raman measurements the particles were exposed to room air, and hence, the RH was not controlled.

\section{Laboratory results and discussion}

Shown in Fig. 1b are examples of images recorded during a typical experiment in which liquid-liquid phase separation and efflorescence were observed (cf. Movie S1). The new data are plotted in Fig. 2 as a function of org:sulf and $\mathrm{O}: \mathrm{C}$, together with previous measurements of oxygenated organic-ammonium sulfate systems (Table 1 and references therein). Figure 2, as well as Figs. S1-S2, reveal that a dividing line emerges from the data, specifically for $\mathrm{O}: \mathrm{C}<0.7$ compared to $\mathrm{O}: \mathrm{C}>0.7$. For $\mathrm{O}: \mathrm{C}<0.7$, the particles regularly undergo liquid-liquid phase separation, followed by efflorescence of the core with decreasing RH.

The spatial distribution of the organic and sulfate materials after liquid-liquid phase separation in a particle is shown in Fig. 3. The morphology is an organic coating surrounding an aqueous ammonium sulfate core, with small amounts of each in the other phase. For some systems we also observed several sulfate rich inclusions with diameters on the order of a few micrometers within an organic rich phase. These results are consistent with the Raman spectra and optical images of poly(ethylene glycol)-ammonium sulfate particles after liquid-liquid phase separation (Ciobanu et al., 2009). In our studies, as well as the previous studies with poly(ethylene glycol)-ammonium sulfate particles, the hydrophobic glass slide may influence the morphology. Studies with levitated particles have reported an organic lens on aqueous droplets and several small aqueous ammonium sulfate inclusions suspended in an organic particle after liquid-liquid phase separation (Buajarern et al., 2007; Kwamena et al., 2010). Regardless of the morphology, the Raman spectra show that the nucleation-disrupting organic molecules are largely excluded from the aqueous salt solution after phase separation. This separation allows efflorescence to occur at an RH close to that of pure aqueous ammonium sulfate (Ciobanu et al., 2009; Smith et al., 2011).

The SRH value is independent of org:sulf in most cases, as illustrated in Fig. 2a and b, but correlates to first degree with O:C $\left(R^{2}=0.87\right.$ for O:C $\leq 0.8$; Fig. S2), at least for the parameter space explored here (i.e., $0.1<$ org:sulf $<15$ and $0.2<\mathrm{O}: \mathrm{C}<1.4)$. For $\mathrm{O}: \mathrm{C}<0.7$, Fig. $2 \mathrm{c}$ demonstrates that as a first-order approximation ERH and DRH do not depend on org:sulf. Within experimental uncertainty, they are the same as those of pure ammonium sulfate. Conversely, for $\mathrm{O}: \mathrm{C}>0.7$ Fig. $2 \mathrm{~d}$ shows that ERH and DRH decrease with increasing values of org:sulf.

The correlation between SRH and O:C shown in Fig. 2 and Fig. S2 can be rationalised by the salting out effect and the molar polarisation of the organic molecule. The decrease in solubility of an organic molecule in an aqueous solution due to the addition of a salt is known as the salting out effect. Salting out may be described by the Setchenov equation (Lee, 1997):

$\ln \frac{S}{S_{0}}=k_{\mathrm{s}} C_{\mathrm{s}}$

where $S$ is the solubility of the organic molecule in water in the presence of the salt, $S_{0}$ is the solubility in water without the salt, $C_{\mathrm{s}}$ is the concentration of the salt, and $k_{\mathrm{s}}$ is the Setchenov constant. Increasingly negative values of $k_{\mathrm{s}}$ result in a greater tendency of an aqueous organic-inorganic particle to liquid-liquid phase separate. According to electrostatic theories, $k_{\mathrm{s}}$ is related to the molar polarization $\left(P_{\mathrm{m}}\right)$ of the organic molecule (Desnoyers and Ichhaporia, 1969). Since $P_{\mathrm{m}}$ is related to the polarisability and the dipole moment and, furthermore, since polarisability and dipole moment should be roughly related to $\mathrm{O}: \mathrm{C}$, one would expect a correlation between $k_{\mathrm{S}}$ and O:C and also a correlation between SRH and $\mathrm{O}: \mathrm{C}$. This line of thinking is also consistent with a recent modeling study using alcohols and salts that showed that hydrophilicity, which was reflected in O:C, is a key feature in defining the region of a miscibility gap (Zuend et al., 2010). The gap between 0.87 and unity for the correlation factor of SRH with O:C (see Fig. S2) is plausibly explained by the combination of several different classes of organic molecules in our data set. A better correlation would be expected if a homologous series of organic molecules were studied.

In regard to the trends in DRH and ERH shown in Fig. 2, if a liquid-liquid phase separation occurs in a three-component system, the DRH and ERH values are expected to be closer to the binary system (inorganic and water) because in many 
Table 1. List of the data sets used for the parameterisations of SRH, ERH, and DRH in three-component systems (i.e. one organic plus ammonium sulfate and water). Phase transitions were measured for temperatures ranging from 290 to 298 K. Over this temperature range ERH and DRH does not strongly depend on temperature (Colberg et al., 2003; Bodsworth et al., 2010). Initial work with trihydroxyhexane and ammonium sulfate mixtures also suggest that SRH does not strongly depend on temperature over this narrow temperature range. The DRH values reported here corresponds to the total DRH, which indicates where ammonium sulfate completely dissolves. For DRH and SRH we only included results from either bulk measurements or optical microscopy measurements because other techniques typically used for exploring the hygroscopic properties of aerosol particles can miss total deliquescence. For ERH we focused exclusively on optical microscopy measurements to be consistent with the new results reported in the current manuscript. Optical microscopy has been shown to be in good agreement in most cases with other techniques used to measure ERH properties of particles (Parsons et al., 2004). We excluded ERH results if the ERH data increased with an increase in the org:sulf ratio. In this case, efflorescence most likely was due to crystallization of the organic material (a process that likely does not occur under most atmospheric conditions) (Marcolli et al., 2004). The complete data set is plotted in Fig. S1 as colour maps to illustrate that the data covers a wide range of org:sulf and O:C values without any large gaps in this phase space.

\begin{tabular}{|c|c|c|c|c|}
\hline Compound & Formula & Functional Groups & $\mathrm{O}: \mathrm{C}$ & Data Available \\
\hline diethyl decanedioate & $\mathrm{C}_{14} \mathrm{H}_{26} \mathrm{O}_{4}$ & esters & 0.29 & $\mathrm{ERH}^{*}, \mathrm{DRH}^{*}, \mathrm{SRH}^{*}$ \\
\hline 1,2-hexanediol & $\mathrm{C}_{6} \mathrm{H}_{14} \mathrm{O}_{2}$ & alcohols & 0.33 & $\begin{array}{l}\text { DRH (Marcolli and Krieger, 2006), SRH } \\
\text { (Marcolli and Krieger, 2006) }\end{array}$ \\
\hline monomethyl octane-1,8-dioate & $\mathrm{C}_{9} \mathrm{H}_{16} \mathrm{O}_{4}$ & $\begin{array}{l}\text { carboxylic } \\
\text { acid-ester }\end{array}$ & 0.44 & $\mathrm{ERH}^{*}, \mathrm{SRH}^{*}$ \\
\hline 1,4 butanediol & $\mathrm{C}_{4} \mathrm{H}_{10} \mathrm{O}_{2}$ & alcohols & 0.50 & $\begin{array}{l}\text { DRH (Marcolli and Krieger, 2006), SRH } \\
\text { (Marcolli and Krieger, 2006) }\end{array}$ \\
\hline 1,2,6-hexane-triol & $\mathrm{C}_{6} \mathrm{H}_{14} \mathrm{O}_{3}$ & alcohols & 0.50 & $\mathrm{ERH}^{*}, \mathrm{DRH}^{*}, \mathrm{SRH}^{*}$ \\
\hline $\begin{array}{l}\text { 4-dihydroxy-3- } \\
\text { methoxybenzeneacetic acid }\end{array}$ & $\mathrm{C}_{9} \mathrm{H}_{10} \mathrm{O}_{5}$ & $\begin{array}{l}\text { carboxylic } \\
\text { acid-alcohols- } \\
\text { ether-aromatic }\end{array}$ & 0.56 & $\mathrm{ERH}^{*}, \mathrm{DRH}^{*}, \mathrm{SRH}^{*}$ \\
\hline polyethylene glycol-400 & $\begin{array}{l}\mathrm{C}_{2 n} \mathrm{H}_{4 n+2} \mathrm{O}_{n+1} \\
n=8.2 \text { to } 9.1\end{array}$ & alcohols-ethers & $\sim 0.56$ & $\begin{array}{l}\text { ERH (Ciobanu et al., 2009, 2010), DRH } \\
\text { (Marcolli and Krieger, 2006), SRH (Mar- } \\
\text { colli and Krieger, 2006; Ciobanu et al., } \\
\text { 2009) }\end{array}$ \\
\hline 2,5-dihydroxybenzoic acid & $\mathrm{C}_{7} \mathrm{H}_{6} \mathrm{O}_{4}$ & $\begin{array}{l}\text { carboxylic } \\
\text { acid-alcohols }\end{array}$ & 0.57 & $\mathrm{ERH}^{*}, \mathrm{SRH}^{*}$ \\
\hline hexanedioic acid & $\mathrm{C}_{6} \mathrm{H}_{10} \mathrm{O}_{4}$ & carboxylic acids & 0.67 & $\begin{array}{l}\text { DRH (Brooks et al., 2002; Wise et al., } \\
\text { 2003) }\end{array}$ \\
\hline 2,2-dimethylbutanedioic acid & $\mathrm{C}_{6} \mathrm{H}_{10} \mathrm{O}_{4}$ & carboxylic acids & 0.67 & $\mathrm{ERH}^{*}, \mathrm{SRH}^{*}$ \\
\hline pentanedioic acid & $\mathrm{C}_{5} \mathrm{H}_{8} \mathrm{O}_{4}$ & carboxylic acids & 0.8 & $\begin{array}{l}\text { ERH (Pant et al., 2004), DRH (Brooks } \\
\text { et al., 2002; Wise et al., 2003; Pant et al., } \\
\text { 2004; Treuel et al., 2008, 2009), SRH* }\end{array}$ \\
\hline $\begin{array}{l}\text { 6,8-dioxabicyclo[3.2.1]octane- } \\
\text { 2,3,4-triol }\end{array}$ & $\mathrm{C}_{6} \mathrm{H}_{10} \mathrm{O}_{5}$ & ethers-alcohols & 0.83 & $\begin{array}{l}\text { ERH (Parsons et al., 2004), DRH (Parsons } \\
\text { et al., 2004), SRH* }\end{array}$ \\
\hline propane-1,2,3-triol & $\mathrm{C}_{3} \mathrm{H}_{8} \mathrm{O}_{3}$ & alcohols & 1.00 & $\begin{array}{l}\text { ERH (Parsons et al., 2004), DRH (Parsons } \\
\text { et al., 2004; Marcolli and Krieger, 2006), } \\
\text { SRH* }\end{array}$ \\
\hline L-hydroxybutanedioic acid & $\mathrm{C}_{4} \mathrm{H}_{6} \mathrm{O}_{5}$ & carboxylic acids & 1.00 & $\begin{array}{l}\text { DRH (Brooks et al., 2002; Wise et al., } \\
\text { 2003) }\end{array}$ \\
\hline butanedioic acid & $\mathrm{C}_{4} \mathrm{H}_{6} \mathrm{O}_{4}$ & carboxylic acids & 1.00 & $\begin{array}{l}\text { DRH (Brooks et al., 2002; Wise et al., } \\
\text { 2003) }\end{array}$ \\
\hline (Z)-butenedioic acid & $\mathrm{C}_{4} \mathrm{H}_{4} \mathrm{O}_{4}$ & carboxylic acids & 1.00 & $\begin{array}{l}\text { DRH (Brooks et al., 2002; Wise et al., } \\
\text { 2003; Treuel et al., 2009) }\end{array}$ \\
\hline $\begin{array}{l}\text { 2-hydroxypropane-1,2,3- } \\
\text { tricarboxylic acid }\end{array}$ & $\mathrm{C}_{6} \mathrm{H}_{8} \mathrm{O}_{7}$ & $\begin{array}{l}\text { carboxylic acids- } \\
\text { alcohol }\end{array}$ & 1.17 & $\begin{array}{l}\text { ERH (Bodsworth et al., 2010), DRH } \\
\text { (Bodsworth et al., 2010), SRH* }\end{array}$ \\
\hline propanedioic acid & $\mathrm{C}_{3} \mathrm{H}_{4} \mathrm{O}_{4}$ & carboxylic acids & 1.33 & $\begin{array}{l}\text { ERH (Parsons et al., 2004), DRH (Brooks } \\
\text { et al., 2002; Wise et al., 2003; Parsons } \\
\text { et al., 2004; Salcedo, 2006; Treuel et al., } \\
\text { 2008, 2009), SRH* }\end{array}$ \\
\hline
\end{tabular}

\footnotetext{
* This study's data.
} 
Table 2. Parameterisations of the SRH, ERH, and DRH data. In the parameterisations, terms include $x=\log 10$ (org:sulf mass ratio) and $y=\mathrm{O}: \mathrm{C}$ atomic ratio. Data used to develop the parameterizations were recorded at temperatures ranging from 290 to $298 \mathrm{~K}$. Over this temperature range ERH and DRH do not strongly depend on temperature. Initial work with trihydroxyhexane and ammonium sulfate mixtures also suggest that SRH does not strongly depend on temperature over this narrow range.

\begin{tabular}{|c|c|c|c|}
\hline Predictions & Parameterisation & Valid Range & Reduced $\chi^{2}$ \\
\hline \multirow[t]{2}{*}{$\mathrm{SRH}(x, y)$} & $=0$ & $\begin{array}{l}0.7<(\mathrm{O}: \mathrm{C})<1.4 \\
\text { and } 0.1<(\text { org:sulf })<15\end{array}$ & \multirow[t]{2}{*}{43.8} \\
\hline & $=35.50+339.9 y-471.8 y^{2}$ & $\begin{array}{l}0.2<(\mathrm{O}: \mathrm{C})<0.7 \text { and } 0.1 \\
<(\text { org:sulf })<15\end{array}$ & \\
\hline \multirow[t]{2}{*}{$\operatorname{ERH}(x, y)^{*}$} & $\begin{array}{l}=130.3+196.3 x-189.9 y+123.7 x^{2}- \\
370.7 x y+73.03 y^{2}+23.18 x^{3}- \\
214.4 x^{2} y+125.0 x y^{2}+0.6104 x^{4}- \\
33.19 x^{3} y+52.19 x^{2} y^{2}\end{array}$ & $\begin{array}{l}0.7<(\mathrm{O}: \mathrm{C})<1.4 \text { and } 0.1 \\
<(\text { org:sulf })<15\end{array}$ & \multirow[t]{2}{*}{2.77} \\
\hline & $=33.06-1.974 x-0.0252 y$ & $\begin{array}{l}0.2<(\mathrm{O}: \mathrm{C})<0.7 \text { and } 0.1 \\
<(\text { org:sulf })<15\end{array}$ & \\
\hline \multirow[t]{2}{*}{$\operatorname{DRH}(x, y)$} & $\begin{array}{l}=107.0+102.7 x-54.53 y+98.79 x^{2}- \\
202.8 x y+22.79 y^{2}+21.82 x^{3}- \\
182.2 x^{2} y+80.75 x y^{2}-1.328 x^{4}- \\
33.99 x^{3} y+57.97 x^{2} y^{2}\end{array}$ & $\begin{array}{l}0.7<(\mathrm{O}: \mathrm{C})<1.4 \text { and } 0.1 \\
<(\text { org:sulf })<3\end{array}$ & \multirow[t]{2}{*}{0.92} \\
\hline & $=79.91-0.0618 x+0.0910 y$ & $\begin{array}{l}0.2<(\mathrm{O}: \mathrm{C})<0.7 \text { and } 0.1 \\
<(\text { org:sulf })<15\end{array}$ & \\
\hline
\end{tabular}

* Negative ERH values correspond to the absence of efflorescence (i.e., no efflorescence is predicted even at $0 \% \mathrm{RH}$ ).

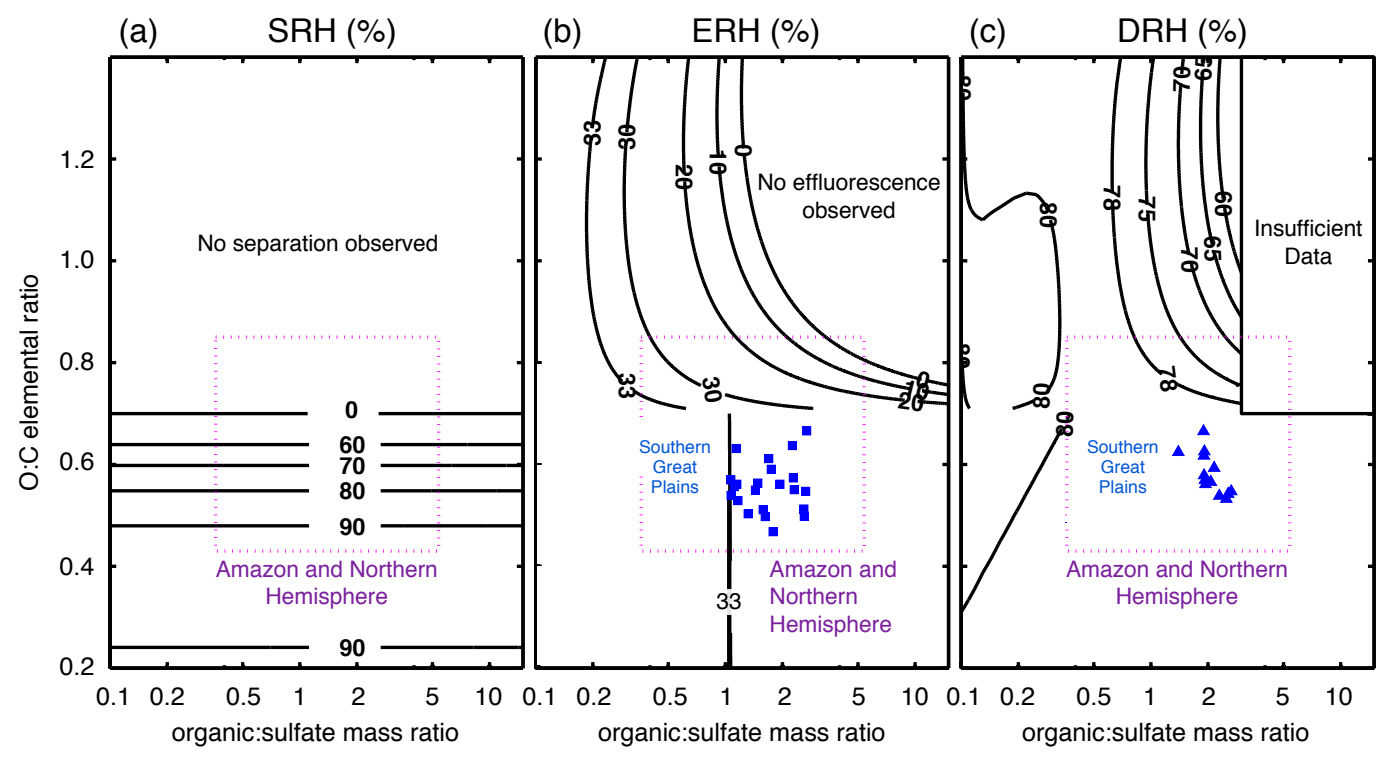

Fig. 4. Contour plots of SRH, ERH, and DRH based on the presented parameterisations of the experimental data. The magenta boxes enclose org:sulf and O:C values (campaign averages) measured in the pristine Amazon Basin (Chen et al., 2009) and many locations in the Northern Hemisphere (Jimenez et al., 2009; Ng et al., 2010). The blue symbols in (b) and (c) correspond to field measurements of ERH and DRH that were carried out at the Southern Great Plains (SGP), Oklahoma, USA (Martin et al., 2008). Since instruments commonly used to measure phase transitions in the field are not capable of directly measuring liquid-liquid phase separations, there are no field observations included in (a). Contours apply to temperatures ranging from 290 to $298 \mathrm{~K}$. 
cases after phase separation the organic molecules are expected to partition mostly to the organic phase. This expectation is supported by thermodynamic calculations and measurements (Clegg et al., 2001; Chang and Pankow, 2006; Ciobanu et al., 2009; Zuend et al., 2010). If liquid-liquid phase separation of a three-component system does not occur, a decrease in the DRH and ERH values of ammonium sulfate is expected with an increase in the org:sulf ratio, as implied by the Gibbs-Duhem relation. The Gibbs-Duhem relation states that an increase in the org:sulf ratio must correspond to an increase in the chemical potential of the organic material and a decrease in the chemical potential of ammonium sulphate for the assumption that activity coefficients do not behave atypically (Denbigh, 1981). The implication based on this relation for an increase in the org:sulf ratio are the following: a decrease in the solution saturation with respect to ammonium sulfate for a constant $\mathrm{RH}$; a decrease in the DRH to maintain unity saturation; and a decrease in the ERH to maintain critical supersaturation.

The laboratory data listed in Table 1 and presented in Fig. 2 were parameterized as function of org:sulf and O:C. For O:C $<0.7$, we fit the ERH and DRH values to a firstorder polynomial in terms of both org:sulf and O:C. For $\mathrm{O}: \mathrm{C}>0.7$, higher-order polynomials were required because ERH and DRH are stronger functions of these parameters over this range. At an org:sulf value of 0.1, the DRH was constrained to $80 \% \mathrm{RH}$ to be consistent with the thermodynamic calculations for pure ammonium sulfate (Clegg et al., 1998), and ERH was constrained to $35 \%$ RH to be consistent with ERH values for pure ammonium sulfate determined with the optical microscope technique (Parsons et al., 2004). For SRH, the data were parameterized using a second-order polynomial in O:C only. Figure $2 \mathrm{a}-\mathrm{b}$ show that SRH is relatively insensitive to org:sulf. The parameterisations are included in Table 2 and are plotted in Fig. 4.

To evaluate the goodness-of-fit of the parameterisations, we calculated the reduced $\chi^{2}$ values (see Table 2) as well as the residuals (Fig. 5). For ERH and DRH, the reduced $\chi^{2}$ values were 2.77 and 0.92 , respectively. Values close to 1 are considered good fits. The residuals appeared randomly distributed, as expected for good fits. For SRH, the reduced $\chi^{2}$ values were larger (43.8), and the residuals were concentrated mainly for $0.5<\mathrm{O}: \mathrm{C}<0.7$ and org:sulf $>1$. In the region where the residuals were larger $(\mathrm{O}: \mathrm{C}<0.7)$, the reduced $\chi^{2}$ value was 62.2 . The parameterisations correctly predict ERH and DRH within $5 \%$ RH for $84 \%$ and $94 \%$ of the ERH and DRH measurements, respectively. We conclude that, to good approximation, trends in the ERH and DRH of three-component particles (i.e., particles containing one organic plus ammonium sulfate and water) can be predicted with the presented parameterisations. The SRH parameterisation is less accurate: this parameterisation correctly predicts SRH within $15 \%$ RH for $88 \%$ of the measurements (Fig. 5). Nevertheless, the parameterisation does predict with reasonable accuracy the org:sulf and O:C parameter space where liquid-liquid phase separation is expected to occur. For more accurate predictions of SRH, a need for additional information (i.e., in addition to O:C) is indicated. Useful information would include organic functional groups and the organic molecular weight. However, any additional accuracy would come at the expense of added complexity in the parameterisation and may require chemical information that is currently not routinely measured (unlike org:sulf and O:C).

Measurements of average org:sulf and O:C by advanced on-line particle mass spectrometers have become available in the past few years for the central Amazon Basin (Chen et al., 2009) and for many locations in the Northern Hemisphere (Jimenez et al., 2009; Ng et al., 2010). Factor analysis has been used to separate the organic mass spectrum into hydrocarbon-like organic (HOA) and oxygenated organic (OOA) statistical components (Zhang et al., 2005, 2007; Jimenez et al., 2009). Since our parameterisations are applicable to the oxygenated component, we filtered the measurements (Chen et al., 2009; Jimenez et al., 2009; Ng et al., 2010) to include only those regions and times that had high OOA statistical scores compared to HOA scores. The constraint applied was $\mathrm{OOA} /(\mathrm{OOA}+\mathrm{HOA}) \geq 0.85$. The HOA component is believed to represented oily materials that have limited chemical interaction with oxygenated organicsulfate-water components that are the focus of the present study. The sampling locations after filtering were: Riverside, Zurich (summer), Zurich (winter), off New England coast, Fukue, Okinawa, Cheju, Duke Forest, Pinnacle Park, Cheboque Point, Jungfraujoch, Hyytiala, and central Amazon Basin. For these locations, org:sulf and O:C campaign averages ranged from 0.36 to 5.39 and 0.43 to 0.85 respectively (Chen et al., 2009; Jimenez et al., 2009; $\mathrm{Ng}$ et al., 2010). Magenta boxes in Fig. 4 enclose the org:sulf and O:C range covered by these ambient measurements. Coincidence is apparent between the locations of the magenta boxes representing ambient measurements and the org:sulf and O:C range covered by the introduced SRH, ERH, and DRH parameterisations.

\section{Case studies}

\subsection{Environmental chamber studies}

The applicability of the derived parameterisations for predicting the phase transitions of multi-component oxygenated organic-sulfate mixtures was tested using secondary organic material (SOM) that was mixed with sulfate and water in individual particles. The SOM was produced by the oxidation of volatile organic compounds (VOCs) in an environmental chamber in the presence of ammonium sulfate seed particles (Shilling et al., 2008; King et al., 2010; Li et al., 2011; Smith et al., 2011). Some of the oxidation products had low vapor pressures and consequently condensed onto the seed particles. Particle-phase SOM produced in an environmental 

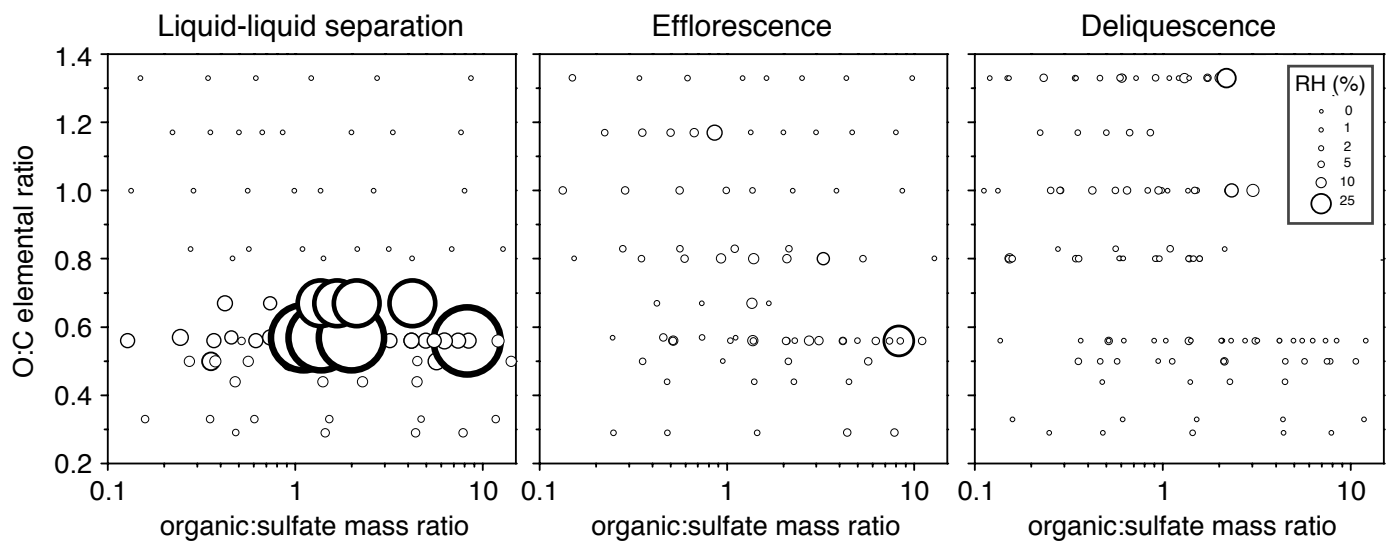

Fig. 5. The residuals (defined as the difference between parameterisations and measurements) for SRH, ERH, and DRH. The diameter of the circles correspond to the difference between the parameterisations and the measurements in \% RH.

(a) a-pinene and $\beta$-caryophyllene SOM

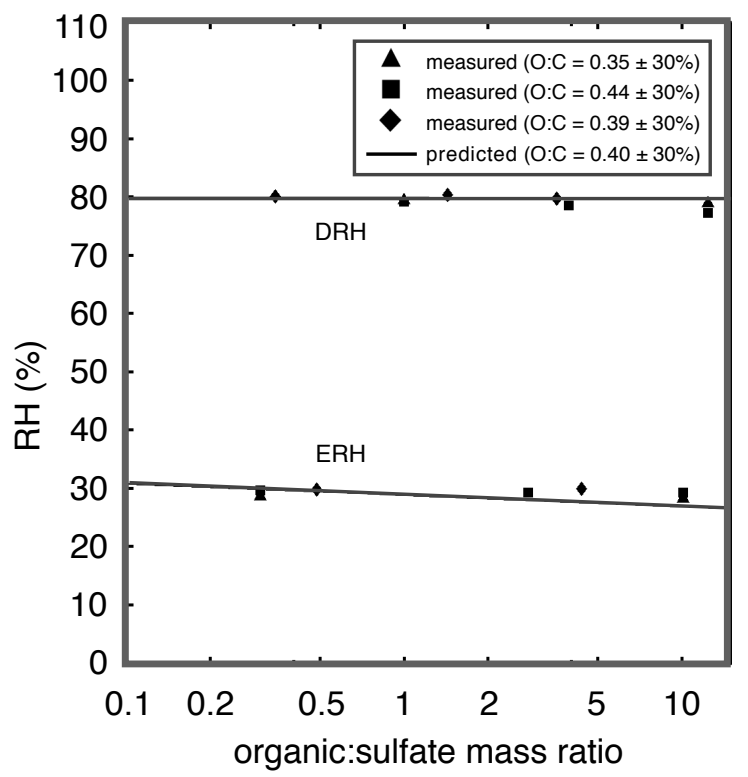

(b) Isoprene SOM

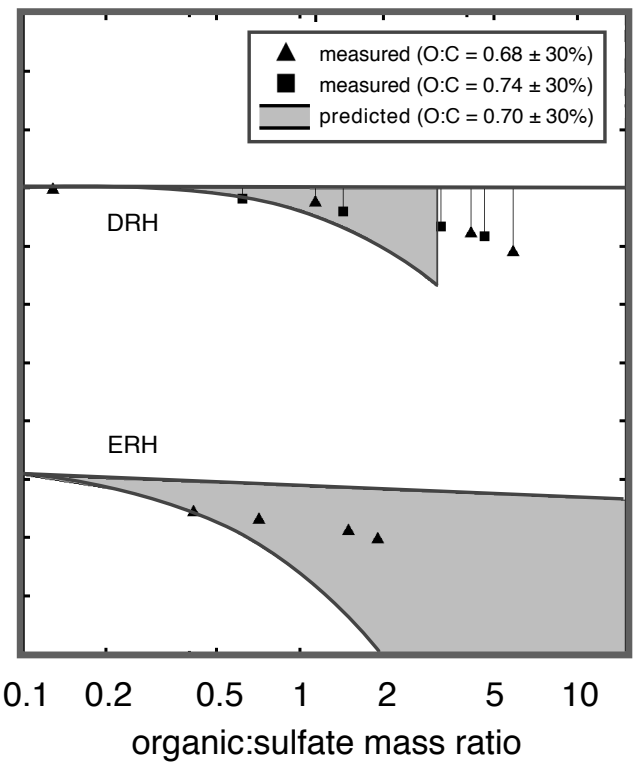

Fig. 6. Comparison between measured and predicted ERH and DRH for organic-sulfate particles. Panel (a) shows observations for organic material produced by the ozonolysis of $\alpha$-pinene and $\beta$-caryophyllene. Panel (b) shows observations for organic material produced by isoprene photooxidation. The predictions shown in each panel represent the ERH and DRH parameterisations with input parameters of the measured org:sulf and O:C, including a maximum $30 \%$ uncertainty in the O:C measurements (Aiken et al., 2007). This uncertainty is relatively less important for (a) (thus narrower bands) than (b) (wider bands) because of the different O:C values. The unsymmetrical error bars for the deliquescence measurements in (b) are discussed in the supplementary material. The ERH parameterisations have been adjusted by $4.2 \% \mathrm{RH}$ to take into account differences in particle size and observation time.

chamber contains 10 s to 100 s of oxygenated compounds and as such represents a surrogate for atmospheric oxygenated organic material. Up to $90 \%$ of the particle-phase submicron organic material in the atmosphere is SOM (Hallquist et al., 2009). The ERH and DRH of the mixed SOM organicammonium sulfate particles were measured using a tandem differential mobility analyzer (cf. supplementary material and references Rosenoern et al., 2009; Smith et al., 2011).
The org:sulf and O:C ratios were measured using on-line mass spectrometry (DeCarlo et al., 2006; Aiken et al., 2008; Shilling et al., 2009), including recent updates for SOM water peaks (Chen et al., 2011).

Particles probed by the $1 \times 3$ TDMA were approximately $0.150 \mu \mathrm{m}$ and the observation time was on the order of $1 \mathrm{~s}$. The ERH parameterisation was based on microscope measurements of particles with diameters ranging from 10 to 
$30 \mu \mathrm{m}$ and observation times of $60 \mathrm{~s}$ at each RH. Since ERH depends on the particle size and observation time (Martin, 2000; Gao et al., 2006), an adjustment was made when comparing the ERH parameterizations with the $1 \times 3$ TDMA ERH results. The ERH parameterization was adjusted by $4.2 \% \mathrm{RH}$ so that the $1 \times 3$ TDMA ERH results for pure ammonium sulfate was in agreement with microscope results for the same particle composition.

Figure 6 shows both the ERH and DRH measurements (points) as well as the predictions (lines) obtained using the ERH and DRH parameterisations, with input parameters of the measured org:sulf and O:C. The ERH parameterisation has been adjusted by $4.2 \% \mathrm{RH}$ as discussed above. The derived parameterisation tested against the independent ERH and DRH measurements of the chamber particles was accurate within $4.4 \% \mathrm{RH}$ for all observations.

\subsection{Field studies}

The parameterisations were also tested against measurements that took place during June 2007 in the Southern Great Plains (SGP), Oklahoma, USA (cf. supplementary material and references (Sheridan et al., 2001; Martin et al., 2008)). For the current analysis, we considered measurements for which the cation mole fraction arising from $\mathrm{NH}_{4}^{+}$was greater than 0.75 and the anion mole fraction arising from $\mathrm{SO}_{4}^{2-}$ was greater than 0.90. The use of this subset ensured that the inorganic composition was close to ammonium sulfate and that any deviations in the ERH and DRH due to incomplete neutralisation or the presence of the nitrate anion were relatively small. Both of these factors have been demonstrated in laboratory studies to influence ERH and DRH (Martin et al., 2003). The org:sulf and O:C ratios at which efflorescence and deliquescence occurred at SGP are plotted in Fig. 4b and c, alongside the RH contours of the parameterisations. The parameterisations predict that the DRH should lie within the ranges of $78-80 \%$, in reasonable agreement with the DRH observations at SGP, which ranged from $77-79 \%$. The parameterisations predict that the ERH should lie within the range of 26-31\% (after correcting for the difference in particle size and observation time), in agreement with the ERH observations at SGP, which ranged from 26-29\%.

\section{Conclusions and outlook}

The relative humidity at which liquid-liquid phase separation, efflorescence, and deliquescence occurred in 11 different oxygenated organic-ammonium sulfate systems was studied with an optical microscope. The new laboratory data as well as data reported in the literature was used to develop parameterisations in terms of O:C and org:sulf. The parameterisations correctly predict ERH and DRH for three component laboratory particles within $5 \% \mathrm{RH}$ for $84 \%$ and $94 \%$ of the measurements, respectively. The parameterisations correctly predict SRH within $15 \%$ RH for $88 \%$ of the measurements. Improvements in the predictions of SRH will require additional chemical information which may not be routinely measured. The applicability of the derived parameterisations for predicting the phase transitions of multicomponent organic-ammonium sulfate mixtures were tested using environmental chamber data and field data from the Southern Great Plains, Oklahoma. The environmental chamber ERH and DRH data and field ERH and DRH data agreed with the parameterisations within $4.4 \% \mathrm{RH}$.

The parameterisations presented herein represent a conceptual framework for the liquid-liquid phase separation, efflorescence, and deliquescence of a common class of atmospheric particles, specifically ammonium sulfate-organicwater particles. In outlook, this framework can be generalised to other particle types and conditions in the case that additional data can be obtained. Priorities should include: (1) environmental chamber and field studies with higher O:C values than available in the present study; (2) environmental chamber studies and field studies where predictions of DRH and ERH are sensitive to specific O:C and org:sulf combinations (i.e., $0.7<\mathrm{O}$ :C $<1.4$ and $0.5<$ org:sulf $<5$ ); (3) direct measurements of liquid-liquid phase separation in environmental chamber studies and in the atmosphere; (4) laboratory studies of organic-ammonium sulfate particles that contain functional groups other than the ones used to develop the parameterisations presented here; and (5) studies using a broader range of composition, such as acidic particles or particles enriched in nitrate which are known to decrease ERH and DRH (Martin et al., 2003). Finally, the presented parameterisations were developed for oxygenated organics, non-oxygenated organic molecules (i.e., oily hydrocarbons), which on a global basis are less important than SOM, can still be important locally near or in urban centers (Kanakidou et al., 2005; Zhang et al., 2007; Hallquist et al., 2009). Studies of particles that have large concentrations of both oxygenated organic material and oily hydrocarbons are needed. The interesting story might develop further in such cases in that an additional phase separation might occur (i.e., three-phase liquid particles may form) (Knickerbocker et al., 1982). As a practical matter, the computational burden of the framework presented herein is low. Therefore, the parameterisations are well suited for incorporation in comprehensive chemical transport models (CTMs) (Wang et al., 2008). CTMs are used in large-scale predictions of atmospheric chemistry and are coupled in advanced treatments to global climate models. Future CTMs that incorporate predictions of O:C ratios alongside existing capabilities for organic and sulfate burdens may make use of these types of parameterisations for SRH, ERH, and DRH. 
Supplementary material related to this article is available online at: http://www.atmos-chem-phys.net/11/10995/2011/ acp-11-10995-2011-supplement.zip.

Acknowledgements. This research was supported by the National Sciences and Engineering Research Council of Canada (NSERC) and the USA National Science Foundation under Grant No. 0925467. Any opinions, findings, and conclusions or recommendations expressed in this material are those of the authors and do not necessarily reflect the views of the National Science Foundation. The authors thank K. A. R. Mitchell and K. C. Wong for assistance with the Raman Microscopy measurements, and R. Iannone for assistance with preparing the manuscript.

Edited by: J. H. Seinfeld

\section{References}

Aiken, A. C., DeCarlo, P. F., and Jimenez, J. L.: Elemental analysis of organic species with electron ionization high-resolution mass spectrometry, Anal. Chem., 79, 8350-8358, 2007.

Aiken, A. C., Decarlo, P. F., Kroll, J. H., Worsnop, D. R., Huffman, J. A., Docherty, K. S., Ulbrich, I. M., Mohr, C., Kimmel, J. R., Sueper, D., Sun, Y., Zhang, Q., Trimborn, A., Northway, M., Ziemann, P. J., Canagaratna, M. R., Onasch, T. B., Alfarra, M. R., Prevot, A. S. H., Dommen, J., Duplissy, J., Metzger, A., Baltensperger, U., and Jimenez, J. L.: O/C and OM/OC ratios of primary, secondary, and ambient organic aerosols with high-resolution time-of-flight aerosol mass spectrometry, Environ. Sci. Technol., 42, 4478-4485, 2008.

Anttila, T., Kiendler-Scharr, A., Mentel, T. F., and Tillmann, R.: Size dependent partitioning of organic material: evidence for the formation of organic coatings on aqueous aerosols, J. Atmos. Chem., 57, 215-237, 2007.

Bodsworth, A., Zobrist, B., and Bertram, A. K.: Inhibition of efflorescence in mixed organic-inorganic particles at temperatures less than 250 K, Phys. Chem. Chem. Phys., 12, 12259-12266, 2010.

Braban, C. F. and Abbatt, J. P. D.: A study of the phase transition behavior of internally mixed ammonium sulfate - malonic acid aerosols, Atmos. Chem. Phys., 4, 1451-1459, doi:10.5194/acp4-1451-2004, 2004.

Brooks, S. D., Wise, M. E., Cushing, M., and Tolbert, M. A.: Deliquescence behavior of organic/ammonium sulfate aerosol, Geophys. Res. Lett., 29, 1917, doi:10.1029/2002GL014733, 2002.

Buajarern, J., Mitchem, L., and Reid, J. P.: Characterizing multiphase organic/inorganic/aqueous aerosol droplets, J. Phys. Chem. A, 111, 9054-9061, 2007.

Buzorius, G., Zelenyuk, A., Brechtel, F., and Imre, D.: Simultaneous determination of individual ambient particle size, hygroscopicity and composition, Geophys. Res. Lett., 29, 1974, doi:10.1029/2001GL014221, 2002.

Chang, E. I. and Pankow, J. F.: Prediction of activity coefficients in liquid aerosol particles containing organic compounds, dissolved inorganic salts, and water - Part 2: Consideration of phase sep- aration effects by an X-UNIFAC model, Atmos. Environ., 40, 6422-6436, 2006.

Chen, Q., Farmer, D. K., Schneider, J., Zorn, S. R., Heald, C. L., Karl, T. G., Guenther, A., Allan, J. D., Robinson, N., Coe, H., Kimmel, J. R., Pauliquevis, T., Borrmann, S., Pöschl, U., Andreae, M. O., Artaxo, P., Jimenez, J. L., and Martin, S. T.: Mass spectral characterization of submicron biogenic organic particles in the Amazon Basin, Geophys. Res. Lett., 36, L20806, doi:10.1029/2009GL039880, 2009.

Chen, Q., Liu, Y. J., Donahue, N. M., E., S. J., and Martin, S. T.: Particle-phase chemistry of secondary organic material: Modeled compared to measured $\mathrm{O}: \mathrm{C}$ and $\mathrm{H}: \mathrm{C}$ elemental ratios provide constraints, Environ. Sci. Technol., 45, 4763-4770, doi:10.1021/es104398s, 2011.

Ciobanu, V. G., Marcolli, C., Krieger, U. K., Weers, U., and Peter, T.: Liquid-liquid phase separation in mixed organic/inorganic aerosol particles, J. Phys. Chem. A, 113, 10966-10978, 2009.

Ciobanu, V. G., Marcolli, C., Krieger, U. K., Zuend, A., and Peter, T.: Efflorescence of ammonium sulfate and coated ammonium sulfate particles: evidence for surface nucleation, J. Phys. Chem. A, 114, 9486-9495, 2010.

Clegg, S. L., Brimblecombe, P., and Wexler, A. S.: Thermodynamic Model of the System $\mathrm{H}^{+}-\mathrm{NH}_{4}^{+}-\mathrm{SO}_{4}^{-}-\mathrm{NO}_{3}^{-}-\mathrm{H}_{2} \mathrm{O}$ at Tropospheric Temperatures, J. Phys. Chem. A, 102, 2137-2154, 1998.

Clegg, S. L., Seinfeld, J. H., and Brimblecombe, P.: Thermodynamic modelling of aqueous aerosols containing electrolytes and dissolved organic compounds, J. Aerosol Sci., 32, 713-738, 2001.

Colberg, C. A., Luo, B. P., Wernli, H., Koop, T., and Peter, T.: A novel model to predict the physical state of atmospheric $\mathrm{H}_{2} \mathrm{SO}_{4} / \mathrm{NH}_{3} / \mathrm{H}_{2} \mathrm{O}$ aerosol particles, Atmos. Chem. Phys., 3, 909-924, doi:10.5194/acp-3-909-2003, 2003.

Day, D. A., Takahama, S., Gilardoni, S., and Russell, L. M.: Organic composition of single and submicron particles in different regions of western North America and the eastern Pacific during INTEX-B 2006, Atmos. Chem. Phys., 9, 5433-5446, doi:10.5194/acp-9-5433-2009, 2009.

DeCarlo, P. F., Kimmel, J. R., Trimborn, A., Northway, M. J., Jayne, J. T., Aiken, A. C., Gonin, M., Fuhrer, K., Horvath, T., Docherty, K. S., Worsnop, D. R., and Jimenez, J. L.: Field-deployable, high-resolution, time-of-flight aerosol mass spectrometer, Anal. Chem., 78, 8281-8289, 2006.

Denbigh, K. C.: The Principles of Chemical Equilibrium, Cambridge University Press, Cambridge, 1981.

Desnoyers, J. E. and Ichhaporia, F. M.: Salting-in and salting-out of polar nonelectrolytes, Can. J. Chem., 47, 4639-4643, 1969.

Dibb, J. E., Talbot, R. W., Klemm, K. I., Gregory, G. L., Singh, H. B., Bradshaw, J. D., and Sandholm, S. T.: Asian influence over the western North Pacific during the fall season: Inferences from lead 210, soluble ionic species and ozone, J. Geophys. Res., 101, 1779-1792, 1996.

Dibb, J. E., Talbot, R. W., and Scheuer, E. M.: Composition and distribution of aerosols over the North Atlantic during the Subsonic Assessment Ozone and Nitrogen Oxide Experiment (SONEX), J. Geophys. Res., 105, 3709-3717, 2000.

Erdakos, G. B., Chang, E. I., Pankow, J. F., and Seinfeld, J. H.: Prediction of activity coefficients in liquid aerosol particles containing organic compounds, dissolved inorganic salts, and water 
- Part 3: Organic compounds, water, and ionic constituents by consideration of short-, mid-, and long-range effects using XUNIFAC.3, Atmos. Environ., 40, 6437-6452, 2006.

Finlayson-Pitts, B. J. and Pitts, J. N., J.: Tropospheric air pollution: Ozone, airborne toxics, polycyclic aromatic hydrocarbons, and particles, Science, 276, 1045-1052, 1997.

Forster, P., Ramaswamy, V., Artaxo, P., Berntsen, T., Betts, R., Fahey, D. W., Haywood, J., Lean, J., Lowe, D. C., Myhre, G., Nganga, J., Prinn, R., Raga, G., Schulz, M., and Van Dorland, R.: Changes in Atmospheric Constituents and in Radiative Forcing, in: Climate Change 2007: The Physical Science Basis. Contribution of Working Group I to the Fourth Assessment Report of the IPCC, edited by: Solomon, S., Qin, D., Manning, M., Chen, Z., Marquis, M., Averyt, K. B., Tignor, M., and Miller, H. L., Cambridge University Press, Cambridge, United Kingdom and New York, NY, USA, 2007.

Gao, Y. G., Chen, S. B., and Yu, L. E., J.: Efflorescence relative humidity for ammonium sulfate particles, J. Phys. Chem. A, 110, 7602-7608, 2006.

Hallquist, M., Wenger, J. C., Baltensperger, U., Rudich, Y., Simpson, D., Claeys, M., Dommen, J., Donahue, N. M., George, C., Goldstein, A. H., Hamilton, J. F., Herrmann, H., Hoffmann, T., Iinuma, Y., Jang, M., Jenkin, M. E., Jimenez, J. L., Kiendler-Scharr, A., Maenhaut, W., McFiggans, G., Mentel, Th. F., Monod, A., Prévôt, A. S. H., Seinfeld, J. H., Surratt, J. D., Szmigielski, R., and Wildt, J.: The formation, properties and impact of secondary organic aerosol: current and emerging issues, Atmos. Chem. Phys., 9, 5155-5236, doi:10.5194/acp-95155-2009, 2009.

Huebert, B. J., Howell, S. G., Zhuang, L., Heath, J. A., Litchy, M. R., Wylie, D. J., Kreidler-Moss, J. L., Coppicus, S., and Pfeiffer, J. E.: Filter and impactor measurements of anions and cations during the First Aerosol Characterization Experiment (ACE 1), J. Geophys. Res., 103, 16493-16509, 1998.

Jayne, J. T., Leard, D. C., Zhang, X. F., Davidovits, P., Smith, K. A., Kolb, C. E., and Worsnop, D. R.: Development of an aerosol mass spectrometer for size and composition analysis of submicron particles, Aerosol Sci. Technol., 33, 49-70, 2000.

Jimenez, J. L., Canagaratna, M. R., Donahue, N. M., Prevot, A. S. H., Zhang, Q., Kroll, J. H., DeCarlo, P. F., Allan, J. D., Coe, H., Ng, N. L., Aiken, A. C., Docherty, K. S., Ulbrich, I. M., Grieshop, A. P., Robinson, A. L., Duplissy, J., Smith, J. D., Wilson, K. R., Lanz, V. A., Hueglin, C., Sun, Y. L., Tian, J., Laaksonen, A., Raatikainen, T., Rautiainen, J., Vaattovaara, P., Ehn, M., Kulmala, M., Tomlinson, J. M., Collins, D. R., Cubison, M. J., Dunlea, E. J., Huffman, J. A., Onasch, T. B., Alfarra, M. R., Williams, P. I., Bower, K., Kondo, Y., Schneider, J., Drewnick, F., Borrmann, S., Weimer, S., Demerjian, K., Salcedo, D., Cottrell, L., Griffin, R., Takami, A., Miyoshi, T., Hatakeyama, S., Shimono, A., Sun, J. Y., Zhang, Y. M., Dzepina, K., Kimmel, J., Sueper, D., Jayne, J., Herndon, S. C., Trimborn, A. M., Williams, L. R., Wood, E. C., Middlebrook, A. M., Kolb, C. E., Baltensperger, U., and Worsnop, D. R.: Evolution of organic aerosols in the atmosphere, Science, 326, 1525-1529, 2009.

Kanakidou, M., Seinfeld, J. H., Pandis, S. N., Barnes, I., Dentener, F. J., Facchini, M. C., Van Dingenen, R., Ervens, B., Nenes, A., Nielsen, C. J., Swietlicki, E., Putaud, J. P., Balkanski, Y., Fuzzi, S., Horth, J., Moortgat, G. K., Winterhalter, R., Myhre, C. E. L., Tsigaridis, K., Vignati, E., Stephanou, E. G., and Wilson,
J.: Organic aerosol and global climate modelling: a review, Atmos. Chem. Phys., 5, 1053-1123, doi:10.5194/acp-5-1053-2005, 2005.

King, S. M., Rosenoern, T., Shilling, J. E., Chen, Q., Wang, Z., Biskos, G., McKinney, K. A., Pöschl, U., and Martin, S. T.: Cloud droplet activation of mixed organic-sulfate particles produced by the photooxidation of isoprene, Atmos. Chem. Phys., 10, 3953-3964, doi:10.5194/acp-10-3953-2010, 2010.

Knickerbocker, B. M., Pesheck, C. V., Davis, H. T., and Scriven, L. E.: Patterns of 3-liquid-phase behavior illustrated by alcoholhydrocarbon-water-salt mixtures, J. Phys. Chem., 86, 393-400, 1982.

Kwamena, N. O. A., Buajarern, J., and Reid, J. P.: Equilibrium morphology of mixed organic/inorganic/aqueous aerosol droplets: Investigating the effect of relative humidity and surfactants, J. Phys. Chem. A, 114, 5787-5795, 2010.

Lee, L. L.: A molecular theory of Setchenov's salting-out principle and applications in mixed-solvent electrolyte solutions, Fluid Phase Equilibria, 131, 67-82, 1997.

Lee, Y. N., Weber, R., Ma, Y., Orsini, D., Maxwell-Meier, K., Blake, D., Meinardi, S., Sachse, G., Harward, C., Chen, T. Y., Thornton, D., Tu, F. H., and Bandy, A.: Airborne measurement of inorganic ionic components of fine aerosol particles using the particle-into-liquid sampler coupled to ion chromatography technique during ACE-Asia and TRACE-P, J. Geophys. Res., 108, 8646, doi:10.1029/2002JD003265, 2003.

Li, Y. J., Chen, Q., Guzman, M. I., Chan, C. K., and Martin, S. T.: Second-generation products contribute substantially to the particle-phase organic material produced by $\beta$-caryophyllene ozonolysis, Atmos. Chem. Phys., 11, 121-132, doi:10.5194/acp11-121-2011, 2011.

Liu, S., Takahama, S., Russell, L. M., Gilardoni, S., and Baumgardner, D.: Oxygenated organic functional groups and their sources in single and submicron organic particles in MILAGRO 2006 campaign, Atmos. Chem. Phys., 9, 6849-6863, doi:10.5194/acp9-6849-2009, 2009.

Marcolli, C., Luo, B. P., and Peter, T.: Mixing of the organic aerosol fractions: Liquids as the thermodynamically stable phases, J. Phys. Chem. A, 108, 2216-2224, 2004.

Marcolli, C. and Krieger, U. K.: Phase changes during hygroscopic cycles of mixed organic/inorganic model systems of tropospheric aerosols, J. Phys. Chem. A, 110, 1881-1893, 2006.

Martin, S. T.: Phase transitions of aqueous atmospheric particles, Chem. Rev., 100, 3403-3453, 2000.

Martin, S. T., Schlenker, J. C., Malinowski, A., Hung, H. M., and Rudich, Y.: Crystallization of atmospheric sulfatenitrate-ammonium particles, Geophys. Res. Lett., 30, 2102, doi:10.1029/2003GL017930, 2003.

Martin, S. T., Hung, H.-M., Park, R. J., Jacob, D. J., Spurr, R. J. D., Chance, K. V., and Chin, M.: Effects of the physical state of tropospheric ammonium-sulfate-nitrate particles on global aerosol direct radiative forcing, Atmos. Chem. Phys., 4, 183-214, doi:10.5194/acp-4-183-2004, 2004.

Martin, S. T., Rosenoern, T., Chen, Q., and Collins, D. R.: Phase changes of ambient particles in the Southern Great Plains of Oklahoma, Geophys. Res. Lett., 35, L22801, doi:10.1029/2008GL035650, 2008.

Murphy, D. M., Thomson, D. S., and Mahoney, T. M. J.: In situ measurements of organics, meteoritic material, mercury, and 
other elements in aerosols at 5 to 19 kilometers, Science, 282, 1664-1669, 1998.

Murphy, D. M., Cziczo, D. J., Froyd, K. D., Hudson, P. K., Matthew, B. M., Middlebrook, A. M., Peltier, R. E., Sullivan, A., Thomson, D. S., and Weber, R. J.: Single-particle mass spectrometry of tropospheric aerosol particles, J. Geophys. Res., 11, D23S32, doi:10.1029/2006JD007340, 2006.

Ng, N. L., Canagaratna, M. R., Zhang, Q., Jimenez, J. L., Tian, J., Ulbrich, I. M., Kroll, J. H., Docherty, K. S., Chhabra, P. S., Bahreini, R., Murphy, S. M., Seinfeld, J. H., Hildebrandt, L., Donahue, N. M., DeCarlo, P. F., Lanz, V. A., Prévôt, A. S. H., Dinar, E., Rudich, Y., and Worsnop, D. R.: Organic aerosol components observed in Northern Hemispheric datasets from Aerosol Mass Spectrometry, Atmos. Chem. Phys., 10, 46254641, doi:10.5194/acp-10-4625-2010, 2010.

Pankow, J. F.: Gas/particle partitioning of neutral and ionizing compounds to single and multi-phase aerosol particles. 1. Unified modeling framework, Atmos. Environ., 37, 3323-3333, 2003.

Pant, A., Fok, A., Parsons, M. T., Mak, J., and Bertram, A. K.: Deliquescence and crystallization of ammonium sulfate-glutaric acid and sodium chloride-glutaric acid particles, Geophys. Res. Lett., 31, L12111, doi:10.1029/2004GL020025, 2004.

Pant, A., Parsons, M. T., and Bertram, A. K.: Crystallization of aqueous ammonium sulfate particles internally mixed with soot and kaolinite: Crystallization relative humidities and nucleation rates, J. Phys. Chem. A, 110, 8701-8709, 2006.

Parsons, M. T., Knopf, D. A., and Bertram, A. K.: Deliquescence and crystallization of ammonium sulfate particles internally mixed with water-soluble organic compounds, J. Phys. Chem. A, 108, 11600-11608, 2004.

Parsons, M. T., Riffell, J. L., and Bertram, A. K.: Crystallization of aqueous inorganic-malonic acid particles: Nucleation rates, dependence on size, and dependence on the ammonium-to-sulfate, J. Phys. Chem. A, 110, 8108-8115, 2006.

Pope, C. A. and Dockery, D. W.: Health effects of fine particulate air pollution: Lines that connect, J. Air Waste Manage. Assoc., 56, 709-742, 2006.

Pratt, K. A. and Prather, K. A.: Aircraft measurements of vertical profiles of aerosol mixing states, J. Geophys. Res., 115, D11305, doi:10.1029/2009JD013150, 2010.

Prisle, N. L., Engelhart, G. J., Bilde, M., and Donahue, N. M.: Humidity influence on gas-particle phase partitioning of $\alpha$-pinene + $\mathrm{O}_{3}$ secondary organic aerosol, Geophys. Res. Lett., 37, L01802, doi:10.1029/2009GL041402, 2010.

Ravishankara, A. R.: Heterogeneous and multiphase chemistry in the troposphere, Science, 276, 1058-1065, 1997.

Rosenoern, T., Paulsen, D., and Martin, S. T.: The 1-by-3 tandem differential mobility analyzer for measurement of the irreversibility of the hygroscopic growth factor, Aerosol Sci. Technol., 43, 641-652, 2009.

Russell, L. M., Bahadur, R., and Ziemann, P. J.: Identifying organic aerosol sources by comparing functional group composition in chamber and atmospheric particles, P. Natl. Acad. Sci. USA, 108, 3516-3521, 2011.

Salcedo, D.: Equilibrium phase diagrams of aqueous mixtures of malonic acid and sulfate/ammonium salts, J. Phys. Chem. A, 110, 12158-12165, 2006.

Seinfeld, J. H. and Pandis, S. N.: Atmospheric Chemistry and Physics, Wiley-Interscience, New Jersey, 2006.
Sheridan, P. J., Delene, D. J., and Ogren, J. A.: Four years of continuous surface aerosol measurements from the Department of Energy's Atmospheric Radiation Measurement Program Southern Great Plains Cloud and Radiation Testbed site, J. Geophys. Res., 106, 20735-20747, 2001.

Shilling, J. E., Chen, Q., King, S. M., Rosenoern, T., Kroll, J. H., Worsnop, D. R., McKinney, K. A., and Martin, S. T.: Particle mass yield in secondary organic aerosol formed by the dark ozonolysis of $\alpha$-pinene, Atmos. Chem. Phys., 8, 2073-2088, doi:10.5194/acp-8-2073-2008, 2008.

Shilling, J. E., Chen, Q., King, S. M., Rosenoern, T., Kroll, J. H., Worsnop, D. R., DeCarlo, P. F., Aiken, A. C., Sueper, D., Jimenez, J. L., and Martin, S. T.: Loading-dependent elemental composition of $\alpha$-pinene SOA particles, Atmos. Chem. Phys., 9, 771-782, doi:10.5194/acp-9-771-2009, 2009.

Smith, M. L., Kuwata, M., and Martin, S. T.: Secondary organic material produced by the dark ozonolysis of alpha-pinene minimally affects the deliquescence and efflorescence of ammonium sulfate, Aerosol. Sci. Technol., 45, 225-242, 2011.

Talbot, R. W., Dibb, J. E., and Loomis, M. B.: Influence of vertical transport on free tropospheric aerosols over the central USA in springtime, Geophys. Res. Lett., 25, 1367-1370, 1998.

Treuel, L., Schulze, S., Leisner, T., and Zellner, R.: Deliquescence behaviour of single levitated ternary salt/carboxylic acid/water microdroplets, Farad. Discuss., 137, 265-278, 2008.

Treuel, L., Pederzani, S., and Zellner, R.: Deliquescence behaviour and crystallisation of ternary ammonium sulfate/dicarboxylic acid/water aerosols, Phys. Chem. Chem. Phys., 11, 7976-7984, 2009.

Wang, J., Hoffmann, A. A., Park, R. J., Jacob, D. J., and Martin, S. T.: Global distribution of solid and aqueous sulfate aerosols: Effect of the hysteresis of particle phase transitions, J. Geophys. Res., 113, D11206, doi:10.1029/2007JD009367, 2008.

Wise, M. E., Surratt, J. D., Curtis, D. B., Shilling, J. E., and Tolbert, M. A.: Hygroscopic growth of ammonium sulfate/dicarboxylic acids, J. Geophys. Res., 108, 4638, doi:10.1029/2003JD003775, 2003.

Zhang, Q., Worsnop, D. R., Canagaratna, M. R., and Jimenez, J. L.: Hydrocarbon-like and oxygenated organic aerosols in Pittsburgh: insights into sources and processes of organic aerosols, Atmos. Chem. Phys., 5, 3289-3311, doi:10.5194/acp-5-32892005, 2005.

Zhang, Q., Jimenez, J. L., Canagaratna, M. R., Allan, J. D., Coe, H., Ulbrich, I., Alfarra, M. R., Takami, A., Middlebrook, A. M., Sun, Y., Dzepina, K., Dunlea, E., Docherty, K., DeCarlo, P. F., Salcedo, D., Onasch, T., Jayne, J. T., Miyoshi, T., Shimono, A., Hatakeyama, S., Takegawa, N., Kondo, Y., Schneider, J., Drewnick, F., Borrmann, S., Weimer, S., Demerjian, K., Williams, P., Bower, K., Bahreini, R., Cottrell, L., Griffin, R. J., Rautiainen, J., Sun, J. Y., Zhang, Y. M., and Worsnop, D. R.: Ubiquity and dominance of oxygenated species in organic aerosols in anthropogenically-influenced Northern Hemisphere midlatitudes, Geophys. Res. Lett., 34, L13801, doi:10.1029/2007GL029979, 2007.

Zuend, A., Marcolli, C., Peter, T., and Seinfeld, J. H.: Computation of liquid-liquid equilibria and phase stabilities: implications for RH-dependent gas/particle partitioning of organic-inorganic aerosols, Atmos. Chem. Phys., 10, 7795-7820, doi:10.5194/acp10-7795-2010, 2010. 